\title{
Analysis and evaluation of the environmental impacts of 'upstream' petroleum operations
}

\section{Ammar Irhoma, Daizhong Su* and Martin Higginson}

Advanced Design and Manufacturing Engineering Centre, School of Architecture, Design and the Built Environment, Nottingham Trent University, Nottingham, NG1 4BU, UK

Email: ammar.irhoma@ntu.ac.uk

Email: daizhong.su@ntu.ac.uk

Email: martin.higginson@ntu.ac.uk

*Corresponding author

\begin{abstract}
Sustainability is increasingly considered an essential business function, but in Libya, petroleum companies are slow to address operational issues that could reduce environmental concerns. This study aims to evaluate the environmental impacts of upstream petroleum operations. The methods adopted in the study are a literature review, an environmental impact assessment (EIA) study and qualitative analyses from, fieldwork trials and 56 semi-structured interviews. The results of the study show that the main environmental impacts are aquatic, terrestrial or atmospheric, with the most significant pollutants linked to the latter category, mainly from engine exhausts, turbine emissions, gas flaring and venting. Major environmental degradations are identified in Libyan upstream operations and a number of recommendations formulated minimising their effect. Particular importance is placed on establishing strict sustainability policies and regulations, and the implementation of an environmental management system.
\end{abstract}

Keywords: sustainability; upstream petroleum industry; Libyan petroleum industry; environmental impact assessment; EIA; engineering management.

Biographical notes: Ammar Irhoma is a $\mathrm{PhD}$ researcher in the Advanced Design and Manufacturing Engineering Centre, Nottingham Trent University. $\mathrm{He}$ has a degree in Mechanical Engineering and received his Masters in Mechanical and Manufacturing Engineering. He is also a part-time Lecturer on the BSc (Hons) Product Design course. His research interests include advanced design and manufacturing engineering, sustainability, energy management, life cycle assessments (LCAs) and environmental impact assessment (EIA).

Daizhong $\mathrm{Su}$ is a Professor of Design Engineering and leads the Advanced Design and Manufacturing Engineering Centre at Nottingham Trent University, UK. His research interests include sustainable product development, environmental management, integrated design and manufacturing and web/internet-based engineering. His research has been supported by grants from various founding organisations including European Commission, UK 
research councils and regional development agencies, Royal Society, industries and international organisations. He is the Editor-in-Chief of the International Journal of Design Engineering published by InderScience. He has been involved in organising more than 20 international conferences as Conference Chair, Co-chair, International Chair and committee members. He has about 220 refereed publications.

Martin Higginson is a Senior Lecturer in Product Design at Nottingham Trent University where he has held a number of course leader and year tutor posts. His background is in materials technology which he has taught to engineers and designers for the past 25 years. He is a member of the Institute of Materials, Minerals and Mining and within Nottingham Trent, the Advanced Design and Manufacturing Engineering Centre. His research interests include the sustainable and innovative use of materials and processes, developments in packaging products and new approaches in materials and manufacturing education.

\section{Introduction}

Pressures from the international community including the United Nations are forcing oil-rich countries in the Middle East to improve their environmental record (UNEP, 1997). In Libya, the petroleum industry is the key to realising this, since it represents around $90 \%$ of the country's revenue (Saleh and Ibrahim, 2006). Libya, as of June 2014, has a crude oil reserve of 48.5 billion barrels ( $\mathrm{BPa}, 2014)$, which is considered the largest in Africa. Additionally, Libya believes it has substantial undiscovered potential due to the fact that its land mass is mostly unexplored. Thus, it is vital that the Libyan Government focuses on the development of this sector. Sustainable development (SD) was first mentioned by the World Commission on Environment and Development (WCED) in 1987, through the Brundtland report. SD is defined as "development that meets the needs of the present generation without compromising the ability of future generations to meet their own needs" [WCED, (1987), p.6]. Sustainability is considered as a global challenge for industrial sectors (Bukhari, 2013) and therefore, it requires a holistic move towards adopting sustainability principles and tools. Sustainability has three major and fundamental pillars; the environment, the economy and society. This study focuses on the environmental pillar. The concept of environmental sustainability (ES) is defined as "maintenance of natural capital". Goodland and Daly (1996) suggest that ES is a natural science concept which follows biophysical laws. ES is therefore concerned with protecting the environment from all types of pollution which have severe effects on the planet, such as global warming and other weather changes. It focuses on the reduction of environmental degradation and the use of natural resources.

The petroleum industry is one of the major polluting industries in the world (Schweitzer, 2010). It is the main source of all types of fossil fuels and is rated as the second highest polluting fuels after coal (Ali and Harvie, 2013). International petroleum companies claim they have ES approaches which are implemented to reduce environmental impacts, such as the use of standardised environmental management systems (EMS) like ISO4001 and the Environmental Management and Audit Scheme (EMAS). Some scholars (e.g., Zaky, 2013) would argue that petroleum companies are not 'doing enough' towards the protection of the environment, though Schweitzer (2010) 
states that large international corporations like Shell, BP, and Exxon Mobil have made major strides in the right direction. By comparison, Agnaia (1997), and Al-Drugi and Abdo (2012) state that Libyan petroleum companies do not currently have any schemes in place to tackle the problem. The purpose of this study is to identify and evaluate environmental impacts at the Libyan upstream oil and gas operations and recommend mitigation measures to minimise the identified impacts. The study provides the basis for future research to enable an appropriate EMAS specific to the Libyan petroleum sector to be realised. This type of study is the first of its kind conducted in the Libyan sector and contributes to the ES literature in the context of the Libyan petroleum industry. The petroleum industry commonly consists of three major streams; the upstream, midstream and downstream operations. These streams are defined and the focus in this paper is on the upstream phase. Midstream and downstream phases are studied in future publications as a part of the author's PhD project.

The concept of sustainability came to the fore following the 1987 UN report, Our Common Future, by the Brundtland Commission (WCED, 1987). It was reaffirmed as a goal by the 1992 UN Earth Summit's Agenda 21 and again at the 2002 World Summit on SD in Johannesburg. Sustainability was agreed as a top Millennial Development Goal in 2000 where it was stated "the overarching goal is to define a global action agenda for sustainable development in the twenty first century and beyond." Since then, numerous approaches and concepts have emerged in an attempt to improve ES performance, including environmental impact assessment (EIA), life cycle assessment (LCA) and EMS, i.e., ISO4001. It is noted that such approaches are increasingly implemented within international petroleum companies, but there is little evidence of similar realisation in Libyan petroleum companies (Irhoma et al., 2013). This study, therefore, uses an EIA methodology to assess the environmental impacts of the Libyan petroleum sector and offers a foundation for future implementation of these approaches. The Libyan petroleum sector is chosen for this study because it is a very substantial industry for both the Libyan economy and the European energy supply (Agnaia, 1997). Ali and Harvie (2013) state that the economy of Libya is mainly dependant on the revenues of the petroleum sector which is over $90 \%$ of the total government income. In parallel, $71 \%$ of Libyan petroleum exports are transported to a very demanding market in Europe (European Commission, 2010; EIA, 2014). Another important factor is that, according to the Organisation of the Petroleum Exporting Countries (OPEC, 2014), Libya has the largest petroleum reserve in Africa and the fifth largest in the world, which makes its petroleum sector a very important strategic supply for the long-term stability of European markets. Another reason for the study is the evident lack of literature, research and studies concerning the Libyan petroleum industry. As a Libyan himself, the author is well placed to conduct field trips and investigative research work related to the study and has established a network of contacts to aid this process. Although the petroleum sectors of other Middle Eastern and African countries have similar significance, Libya has a logistical advantage as it is located near to European shores. In addition, the high quality crude oil it produces (according to the American Petroleum institute ratings, it is classified as 'light and sweet') distinguishes it from other neighbouring petroleum sectors. According to Vandewalle (1998), upstream processes are the initial stages of oil and gas operations, which include exploration and offshore and onshore production. The midstream operations involve processing, refining and transportation and the downstream phase includes the activities for marketing, sales and delivery (Nooman and Curtis, 2003). This 
study focused on upstream operations, since in Libya, these operations have not previously been investigated (Goodland, 2013).

\section{The petroleum industry in Libya}

Libya post-1969 has seen considerable industrial and urban development. The Libyan petroleum sector, run by the National Oil Corporations (NOCs), has received a substantial amount of this development. There has been interest in reducing the environmental impacts associated with petroleum operations (Green Oil and Akakus, 2008) since the discovery of oil and gas in Libya. In both, the developed and non-developed world, studies such as $\mathrm{Hu}$ et al. (2013), Gilbuena et al. (2013), and Bruhn-Tysk and Eklund (2002), have attempted to propose solutions to minimise associated impacts, but all of these studies concluded that the identification of impacts and proposed mitigation measures require specific study of the site/project or planet and there is no conclusive solution to support the recommendations. For instance, Bayagbon (2011) recommended creating regulatory bodies tasked directly from the government to oversee the environmental performance at upstream oil and gas operations. Goodland (2013), in his book Libya: The Urgent Transition to Environmental Sustainability, states that the petroleum sector struggles from various major environmental degradations and that there is a significant lack of research studies within the Libyan region. Irhoma et al. (2013) agree and suggest more research in the sector would support decision making and provide more considered solutions to make the sector more environmentally responsible. There are some Libyan studies in the field of ES including Bindra et al. (2014), Mohamed et al. (2013), Al-Drugi and Abdo (2012), Goodland (2013), and Saleh and Ibrahim (2006) and a few general quality improvement studies also exist such as Abusa and Gibson (2013), but these are not specific to the petroleum sector. There is a clear gap in ES research and a significant need for detailed studies to assist the decision-making process. According to Irhoma et al. (2013), the Libyan petroleum industry faces various challenges to implement modern concepts of SD and EMSs. In particular, it was found that leadership and management barriers along with resource issues (human, technical and financial) were the most significant. External political barriers of organisational culture and change were also major hindrances and Irhoma et al. (2013) propose a number of recommendations to enhance employee engagements and compliance with regulations, such as improved management structures and the use of strict policy and legislation, technical support, training and continued improvement approaches, which will all enhance the performance of the oil companies.

The Libyan petroleum sector consists of various large, medium and small companies, which are run by the state owned NOC. The sector includes fully owned national Libyan companies, joint venture companies and other international companies holding exploration and production sharing agreements (EPSA) as well as education and training institutions. Figure 1 illustrates the major institutions which comprise the Libyan petroleum sector.

This study focuses on the early stages of oil operations (exploration and production). Whilst there are upstream petroleum operations in the east of Libya, mainly in Sirte basin and Sidra, the study was conducted in the Murzuq basin area in the west where most oil fields are based. Concentrating field trips to this area also helped with time and cost constraints. The Murzuq basin is located in the south west of Libya about 500 miles south 
of the capital city Tripoli. There are three oil fields in the Murzuq desert visited by the author between February 2013 and June 2013. These are El Sharara oil field owned and managed by the Spanish Repsol Oil Operations Company and El Feel and Al Wafa Oil fields which are both run by Melitah Oil and Gas B.V.

Figure 1 Libyan petroleum industry companies

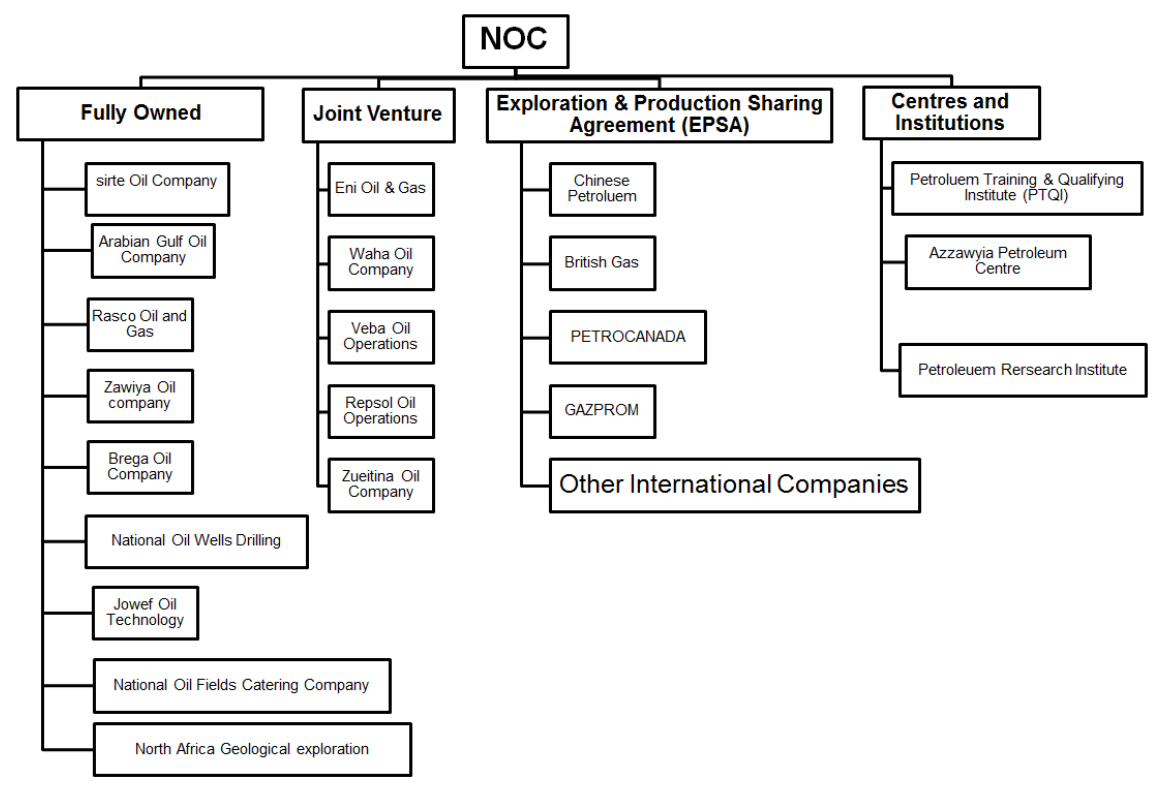

Source: NOC (2014)

The El Sharara oil field was discovered in the 1980s (NOC, 2014). El Feel oil field (which is also called the elephant field) was discovered in 1997 by both the British company LASMO and the Italian ENI oil company. Later, LASMO was purchased by ENI. ENI operating in Libya changed its branch name to Melitah Oil and Gas B.V. and is the company which owns and runs the field in a joint venture agreement with the NOC. Al Wafa oil field was discovered by Shell in 1964 (Melitah Oil and Gas B.V., 2014). Although joint venture companies run these oil fields, they represent a valid sample size of the Libyan upstream petroleum operations. Libyan petroleum companies run by the NOC share very similar management and organisational structures, which suggests the findings here should also be typical for other Libyan petroleum companies. None of the fully owned Libyan companies are involved with the upstream petroleum operations in the western region of Libya, they are mainly involved in midstream and downstream operations such as Azzawyia oil refinery company and Brega oil company. According to the NOC (2014), EPSA operation companies are not involved in the production, but are more used for the discovery of petroleum reservoirs.

Nooman and Curtis (2003) clarify the major activities of the upstream oil and gas operations, which is highlighted in Figure 2. The first activity is exploration (seismic survey). The seismic survey is used after the desk study and aerial survey. The seismic study provides more details on the geology of the area. The hydrocarbons are searched 
within water bodies and rocks, with geological maps studied to locate the sedimentary basin. Aerial photographs are taken to identify promising areas of hydrocarbons like vaults and anticlines (Ikein, 1990). Major wastes are recognised at this stage, which can be categorised as explosive, non-biodegradable flammable and non-flammable.

Figure 2 The sequence of the upstream oil operations

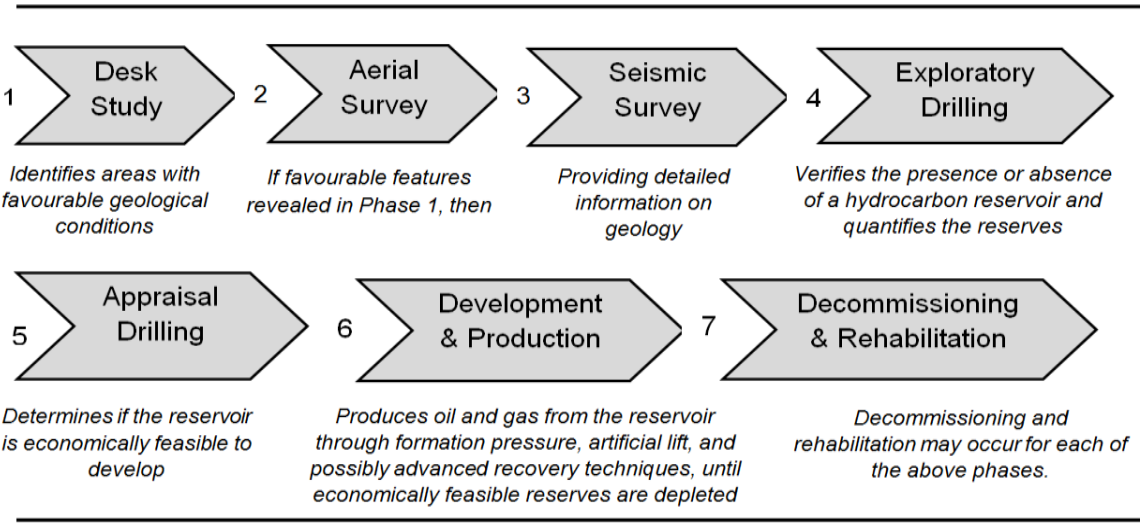

The second activity is the exploratory drilling, which is informed by the seismic survey. This activity confirms the existence of hydrocarbons and estimates the internal pressure of the reservoir; it is then followed by appraisal drilling, which assesses the economic feasibility of the reservoir. Darling (2005) suggests that major environmental impacts are created at this phase mainly through wastes such as oil spills, drilling mud, cuttings, cement waste, chemical wastes, construction materials, and non-burnable waste scrap metals. The final stage of the upstream phase is development and production. This occurs if feasible amounts of hydrocarbon is confirmed in the prior stages and it includes the drilling of additional wells to optimise production and the construction of other facilities to form the oil field. Bayagbon (2011) argues that with all the previous environmental issues, emissions are continuously generated in the atmosphere from flaring, venting and exhausts from engines and machines. It is clear that each barrel of oil is pumped along with several barrels of environmental issues and it is important to understand the classifications of these impacts.

\section{Classification of environmental impacts}

The United Nations Environmental Program (UNEP, 1997) report classified environmental impacts associated with petroleum industry operations into a set of categories. These classifications are further confirmed by Bayagbon (2011) and Bukhari (2013) and are discussed below:

- Human, socio-economic and cultural impacts.

Upstream petroleum operations are likely to cause economic, social and cultural changes. Major impacts include: 
1 land use patterns such as agriculture, land-take and exclusion

2 local population level increase and immigration due to increased access and opportunities

3 availability of, and access to, goods and services such as housing, education, healthcare, water, fuel and electricity brought to the region.

Offshore oil fields in Libya are in the desert where population is very low and public facilities are limited. It should be noted that upstream petroleum operations can have positive changes, such as improved infrastructure, healthcare, education, water supply and other social benefits to local rural communities (Bindra et al., 2014). There is no direct positive contribution, however, to the communities in rural areas; it is hard to find any facilities built for locals and it is essential oil companies start to consider social ES.

- Atmospheric impacts

Atmospheric impacts are all air emissions. Activities at the stage of exploration and production must take account of work procedures and technologies to minimise emissions. Climate change and ozone layer depletion are the key consequences of atmospheric impacts which can be defined as:

1 flaring and venting

2 exhausts of fossil fuels from diesel engines and gas turbines

3 losses from process equipment, tankage and loading operations.

These emissions include green house gases (GHGs).

- Aquatic impacts

Major aquatic impact from upstream operations include: drilling fluids, chemicals of well treatment, cooling water, domestic wastes, sanitary/sewerage and spills/leakages.

- $\quad$ Terrestrial impacts

These are the indirect impacts to soils that arise from physical disturbance as a result of construction or contamination from spillage, leakage or solid waste disposal.

- Potential emergencies

Awareness of potential emergencies should be of paramount importance in petroleum operations and are considered as environmental impacts. Sufficient measures need to be in place to deal with incidents affecting the environment, people and property, which might include:

1 spillage of fuel, oil, gas, hazardous materials and chemicals

2 blowout of oil and gas wells

3 explosions and fires

4 unplanned shutdown events

5 natural disasters including earthquakes, floods, lightening and wars.

Figure 3 shows the typical impacts of the upstream operations. 
Figure 3 Environmental impacts at upstream operations

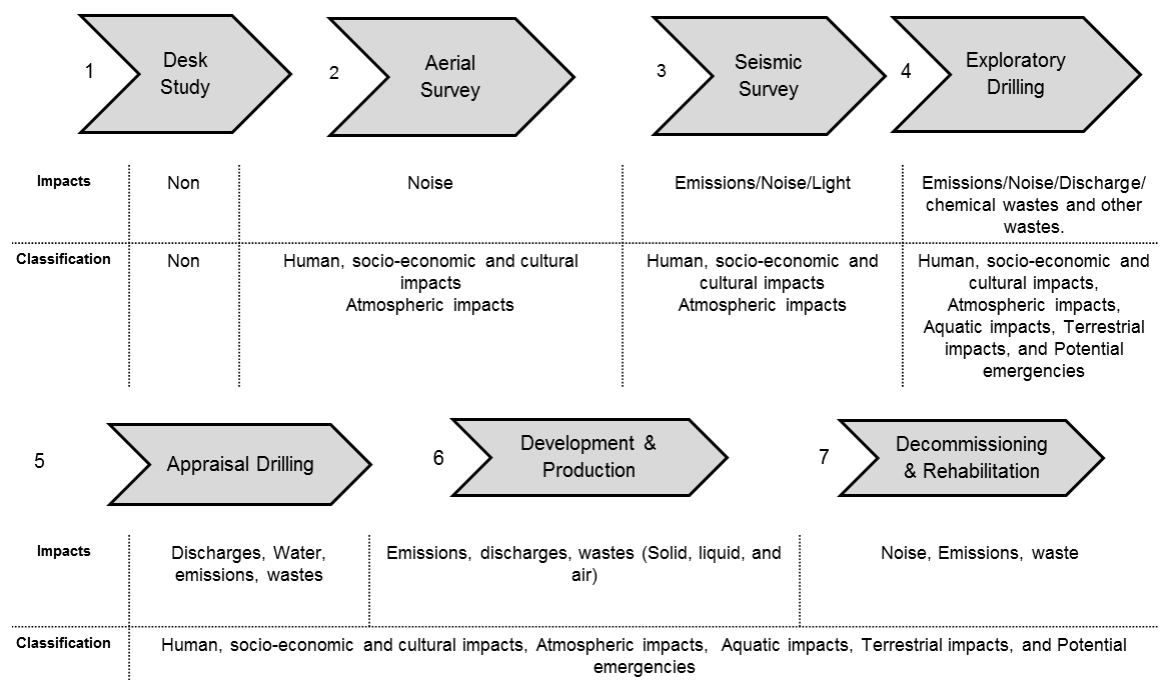

\section{Research methods and the results}

A combination of research methods were utilised to achieve reliable findings. These methods include a literature review, EIA, semi-structured interviews and field trips. The EIA was conducted to assess various impacts at the project location (Murzuq basin) and to provide a guide to the major sources of impacts and potential mitigation measures. The use of EIA highlights specific sources of impacts and their severity based on the EIA UNEP methodology approach by Abaza et al. (2004). In addition to this analysis, 56 semi-structured interviews were conducted to develop a better understanding of the environmental issues in petroleum companies. The interviews were conducted with representatives, engineers, senior managers, environmentalists and stakeholders involved at the upstream petroleum operations, to allow a diverse sample of data and opinions for evaluation (Table 1). Interviews allowed the researcher to gain in depth information about the subject under study and to understand the views of upstream petroleum personnel. The interviews were used to further investigate the environmental impacts and assess how they could be minimised from the interviewee perspective. The findings helped validate the EIA results and provide more reliable conclusions and recommendations. In addition to these techniques, documentary data including unpublished reports mainly from the NOC have been analysed. Two visits to Libya in February and July 2013 were of value to the author. He visited El Feel Oil Field, El Sharara Oil Field, Al Wafa Field and Azzawya Oil refinery. The fieldwork included observation of all field operations, major production plants, pumping stations, treatment, supply systems and storage systems. These fields represent all of the upstream operations in the west of Libya. Azzawya oil refinery represents the importer, processor and exporter of crude oil from these three oil fields. The author conducted this study as a part of his $\mathrm{PhD}$ research project, which included use of an EIA methodology. Many 
practitioner such as Bruhn-Tysk and Eklund (2002), BPb (2002), Abaza et al. (2004), Eidinov (2004) and Gilbuena et al. (2013) claim that EIA is a successful tool to assess the environmental impacts and their risk implications for a specific project area, whereas other tools, such as LCA are more effective to analyse a specific product/process (Garg et al., 2013). The author aims to use LCA for Libyan petroleum products and processes for midstream operations (crude processing and refining) in future publications.

\subsection{Environmental impact assessment}

EIA is one of the major tools used to assist environmental analysis of a project of this nature. It evaluates the degradation that human activities can cause to the environment (Toro et al., 2013) and yields results that assist the decision making process. Wood (2003) states that EIA is the technical key to incorporating environmental protection approaches and to avoiding the loss of natural resources. EIA is widely implemented by various industries around the world, but Ali and Harvie (2013) and Goodland (2013) claim that the Libyan petroleum sector lacks such studies. In order to assess the environmental situation at the upstream phase, EIA was conducted in the Libyan petroleum companies specific to the Murzuq basin project area (Southwest region - El Feel Oil field) and in compliance with the requirements of Libyan Law No. 15 of 1371 (2003), NOC guidelines and best industry practice. This study is very significant in terms of originality as it is the first of its kind conducted in the sector in Libya. The EIA followed the UNEP methodology (Abaza et al., 2004) as well as taking account of the results of the fieldwork and reviews of unpublished reports from the upstream oil companies summarising the physical, biological, and socio-cultural/economic aspects of the oil field sites and surroundings. The assessment methodology as adopted from Modak and Biswas (1999), BPb (2002), Eidinov (2004), and Green Oil and Akakus (2008) are illustrated for quantifying the environmental impacts. The EIA assessment procedure uses the following formulas and calculations to rate the environmental risk. The environmental risk is the combination of the probability of a certain event occurring and the magnitude of its consequences (severity rate). For this procedure, the rate of environmental risk (RER) is calculated as follows:

$$
R E R=P \times S
$$

where $P$ is the probability rate and $S$ is the severity rate. Both $P$ and $S$ require additional calculations to establish the environmental risk. The quantification of the Probability Rate $(P)$ is dependent on two factors:

1 the degree of control on the aspect $(\mathrm{Co})$

2 the frequency of the impact or the aspect $(F r)$

hence:

$$
P=C o+F r
$$

To determine the degree of control, consideration is given to the existence or absence of: written procedures and technical instructions

b contingency plans and training in case of contingency 
c protection or physical barriers

d environmental objectives and targets related to the aspect

e competence (personnel developing the activities)

f monitoring

g a maintenance program.

Considering the above, the degree of control is scored according to the table below:

Table 1 Degree of control $(\mathrm{Co})$

\begin{tabular}{lc}
\hline Degree of control & Value \\
\hline Not controlled aspect & 5 \\
Partially controlled aspect & 3 \\
Controlled aspect & 1 \\
\hline Table $2 \quad$ Frequency (Fr) of impact & \\
\hline Frequency & Value \\
\hline Very frequent & 4 \\
Frequent & 3 \\
Not frequent & 2 \\
Rare & 1 \\
\hline
\end{tabular}

Frequency values of an environmental impact are shown in Table 2.

The assessment of the severity rate $(S)$ as shown in equation (1) requires the analysis of three issues which are:

1 the environment where the impact is affected (environment, Env)

2 the nature of the substance and its hazards (nature, $\mathrm{Na}$ )

3 the magnitude of the impact (magnitude, $M a$ ).

$$
S=E n v+N a+M a
$$

The Environment affected considers the sensitivity of the area impacted.

Table 3 shows the rating.

The nature and hazards of a certain pollutant $(\mathrm{Na})$ considers the physical and chemical characteristics of the pollutant. The ratings are illustrated in Table 4.

In order to establish the magnitude of the impact $(M a)$, it is necessary to measure the amount of resources consumed, the amount of wastes produced and the amount and concentration of the pollutant.

Each impact is assessed using formulas (1), (2) and (3). The RER (RES) calculated will show the amount of risk based on the evaluation of risk categories shown in Table 6 . The risk categories are colour coded and hatched. This methodology was adopted from the general methodology of EIA and as used in EIA studies (BPb, 2002; Kharaka and Otton, 2003; Eidinov, 2004). 
Table 3 The environment (Env)

\begin{tabular}{lc}
\hline Environment affected & Value \\
\hline Ground water, ground or underground sweet water, agricultural land and human & 10 \\
settlements & 8 \\
Protected areas and cultural heritage & 7 \\
Land for livestock activities & 6 \\
air, flora and fauna in a direct way & 3 \\
Land with no agricultural or livestock use, saline water & 1 \\
Land used for installations & \\
\hline
\end{tabular}

Table 4 Nature $(\mathrm{Na})$ of the impact

\begin{tabular}{lc}
\hline Nature & Value \\
\hline Dangerous & 5 \\
Not very dangerous & 3 \\
Not dangerous/there is no pollutant & 0 \\
\hline
\end{tabular}

Table 5 Magnitude $(M a)$ of the impact

\begin{tabular}{|c|c|c|}
\hline Magnitude & Value & \\
\hline Very high & 10 & \\
\hline High & 7 & \\
\hline Medium & 5 & \\
\hline Low & 3 & \\
\hline Negligible & 1 & \\
\hline Risk categories (see online & colours) & \\
\hline \multicolumn{3}{|c|}{ Risk categories } \\
\hline Probability rate $(P) \times$ Severity rate $(S)$ & RES value & Sign \\
\hline Low risk & $<75$ & \\
\hline Minor risk & 75 to 84 & \\
\hline Moderate risk & 85 to 99 & \\
\hline High risk & $>100$ & \\
\hline
\end{tabular}

The results of the EIA are shown in Table 7. The table includes the activity, the aspect and the rate of the environmental impact calculated using the above formulas. In addition, mitigation recommendations are given for each impact. The RER results are colour coded hatched based on the risk categories in Table 6. 
Table $7 \quad$ EIA results and recommendations (see online version for colours)

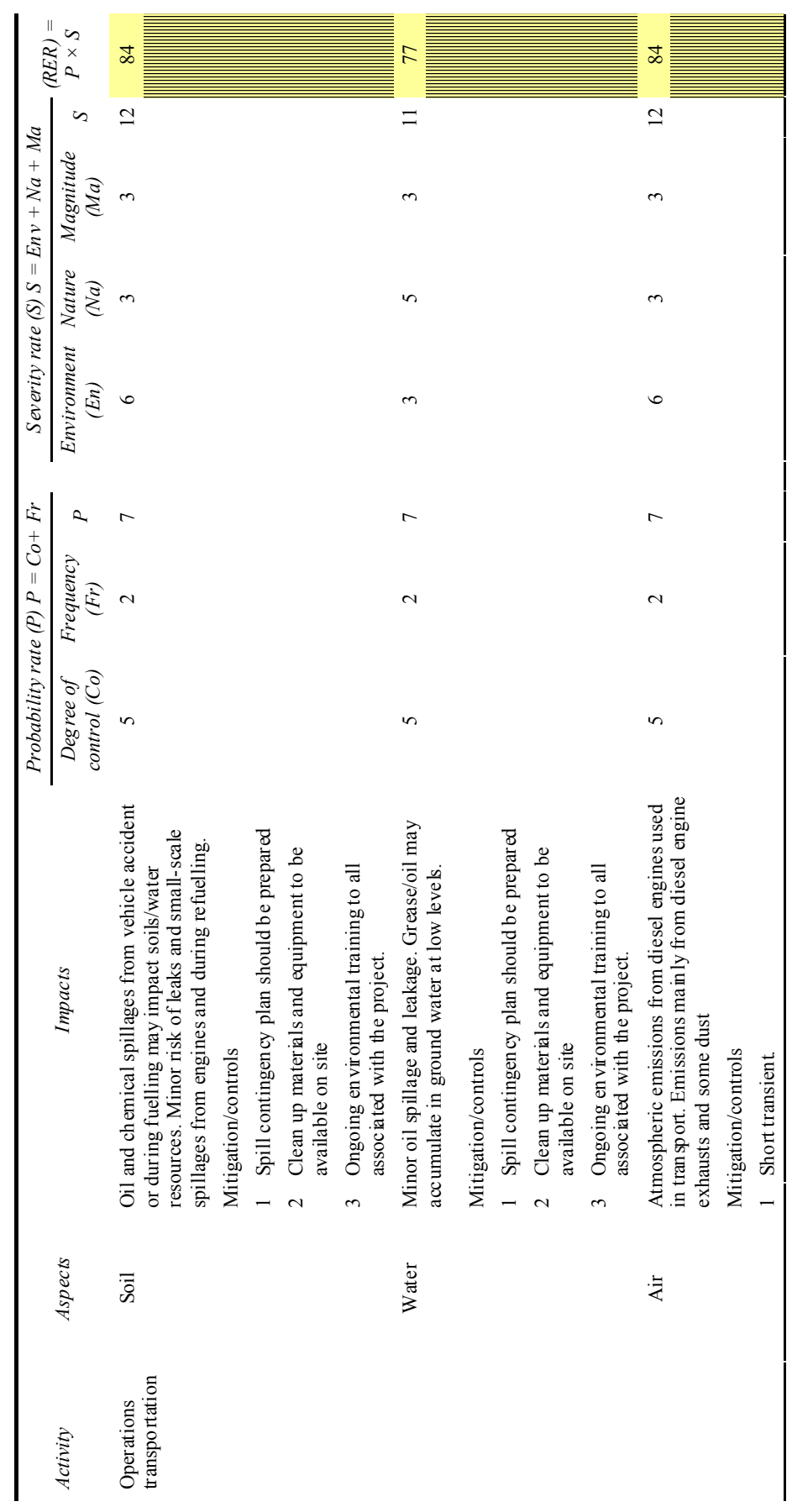


Table 7 EIA results and recommendations (continued) (see online version for colours)

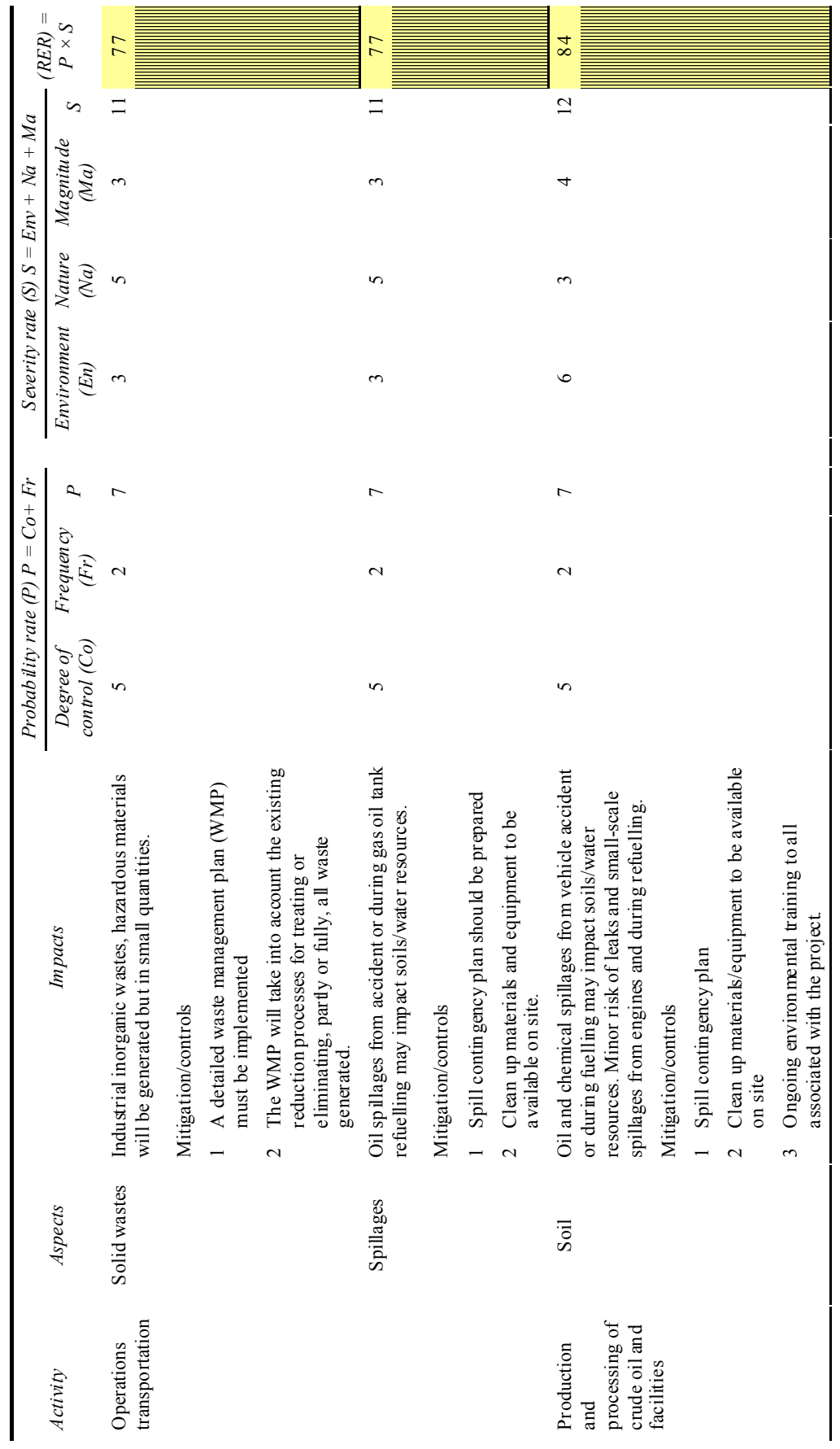


Table 7 EIA results and recommendations (continued) (see online version for colours)

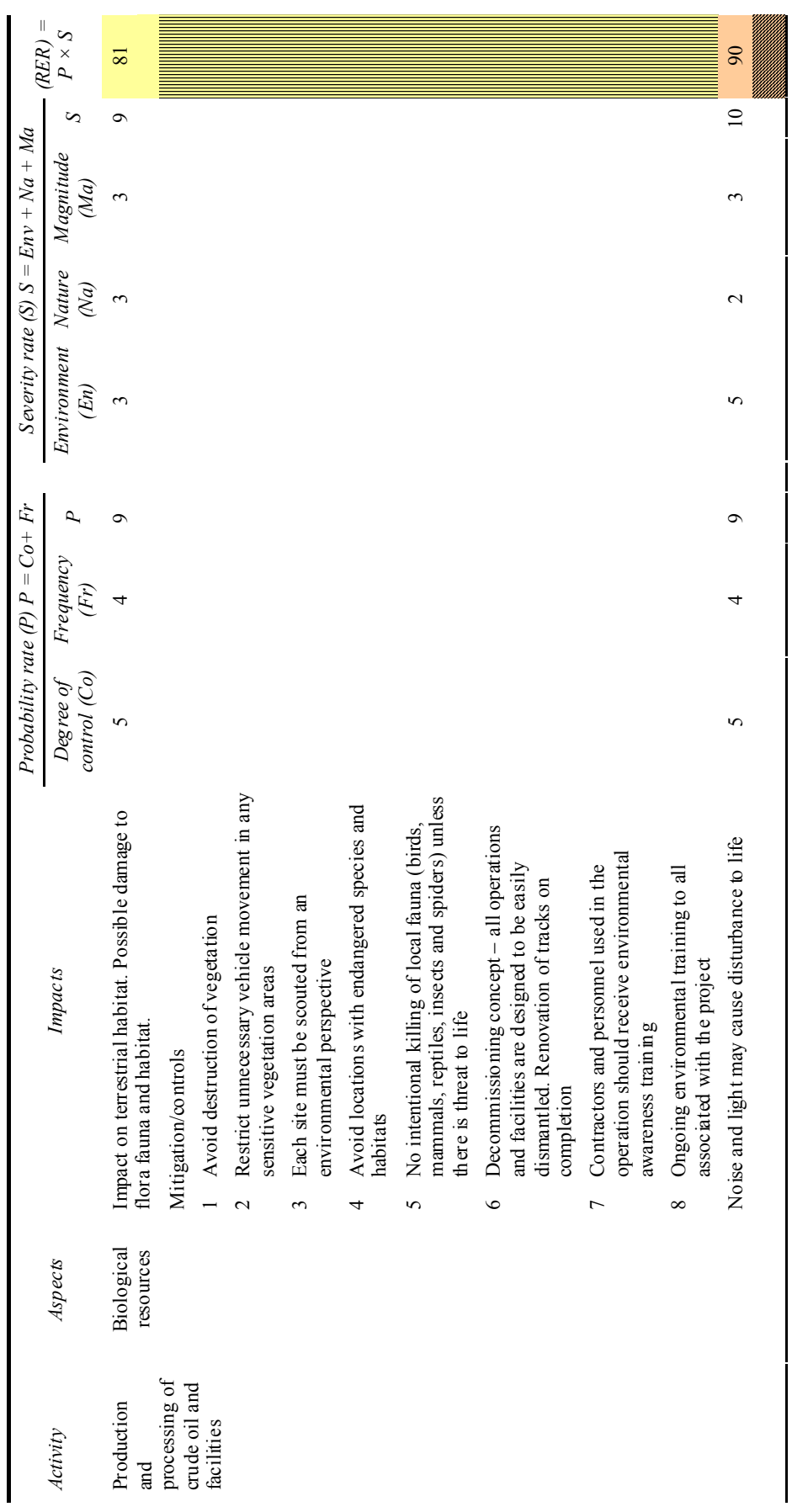


Table 7 EIA results and recommendations (continued) (see online version for colours)

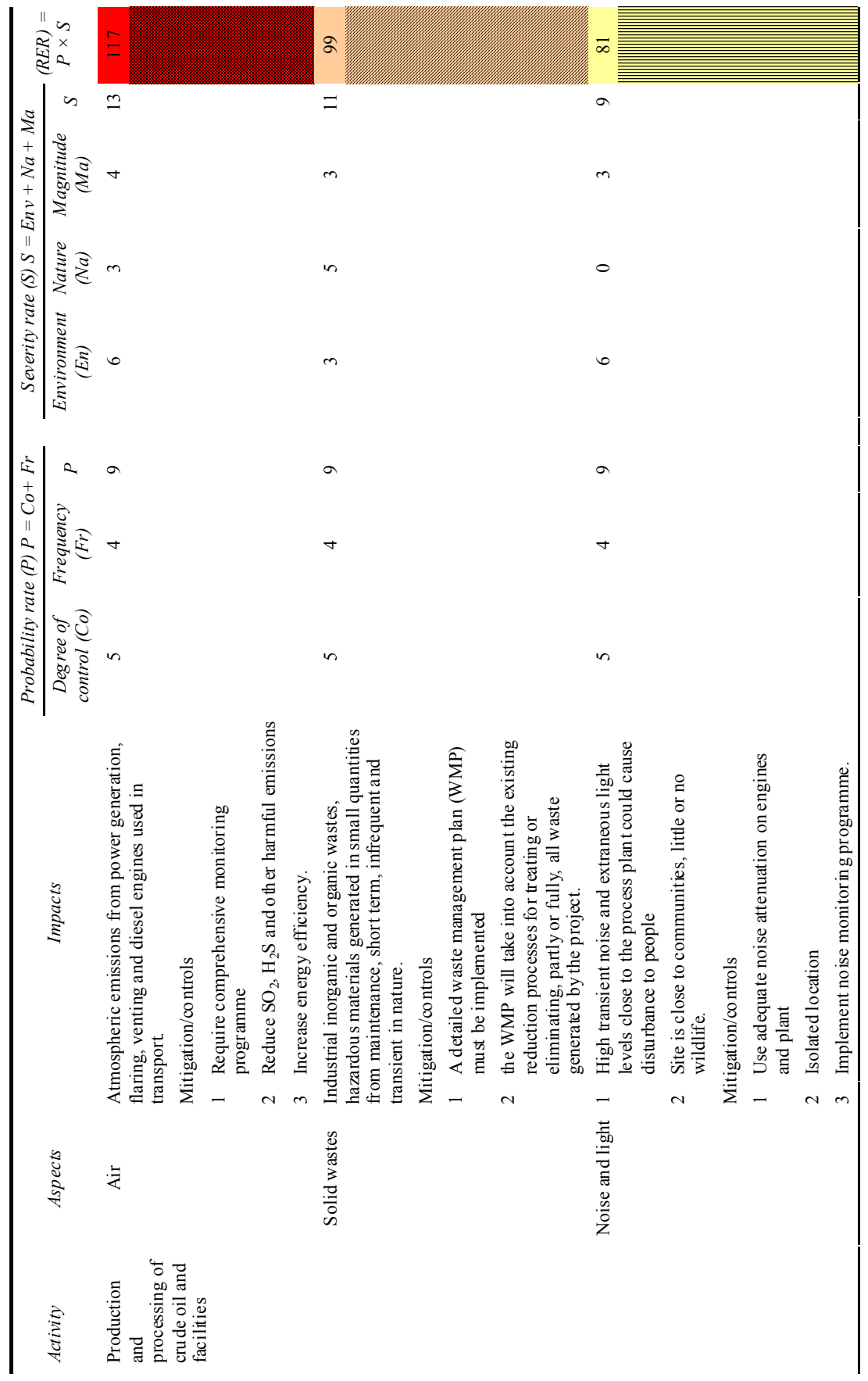


Table 7 EIA results and recommendations (continued) (see online version for colours)

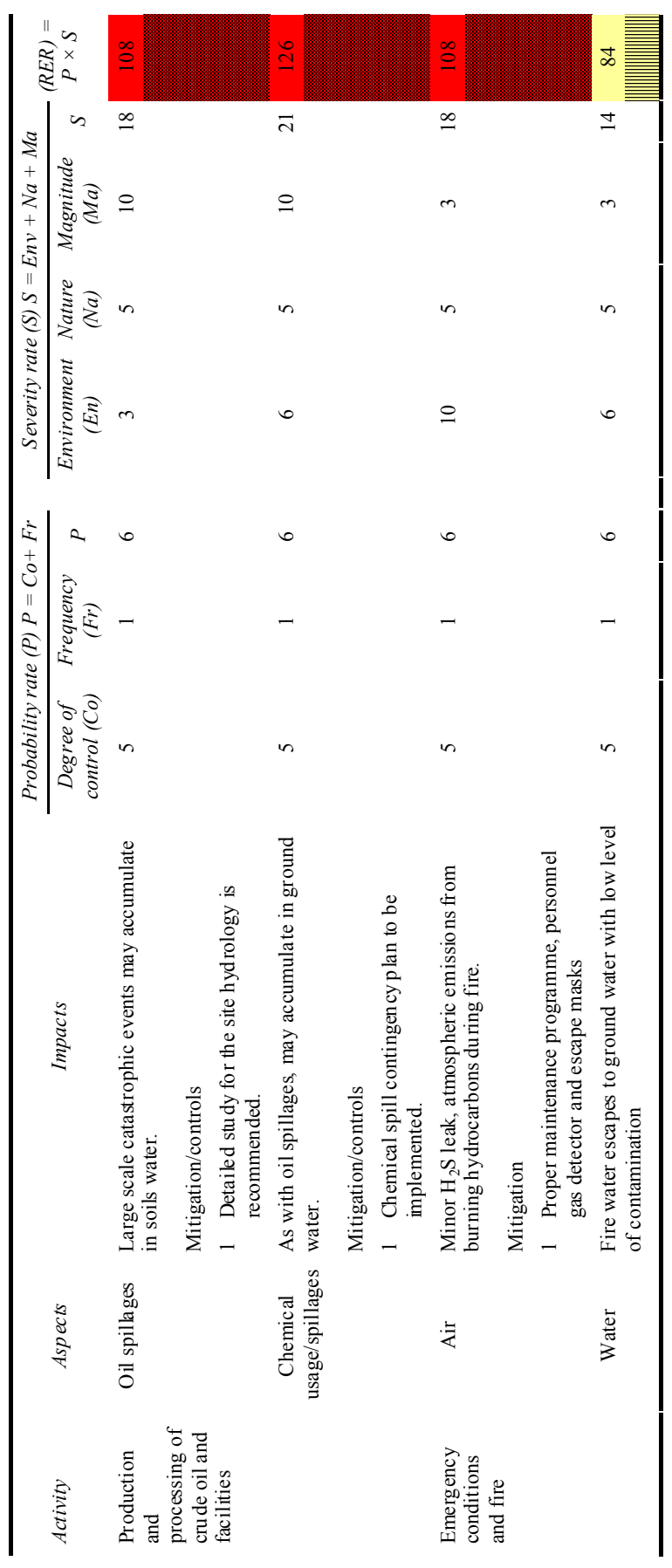


Table 7 shows the calculations conducted for each impact using equations (1), (2) and (3). The table also offers concise mitigation recommendations for each impact. These results reveal that water contamination with hydrocarbons is mainly due to leaks at the field facilities. Thorough evaluation of the extent and source of the pollution is recommended along with a review of the best technologies for soil and water remediation. The air analysis results were gained from unpublished studies at the company carried out to determine the extent of $\mathrm{H}_{2} \mathrm{~S}, \mathrm{VOC}, \mathrm{SO}_{2}, \mathrm{NO}, \mathrm{NO}_{2}, \mathrm{CO}$ and $\mathrm{O}_{3}$ pollutants. It was noted that these results are based on instantaneous measurements, which are not comparable with international standards. A conclusion of the significance of these data can only be drawn following long-term continuous measurements (six months to a year). This data is only indicative of the extent of the pollution; permanent monitoring stations are recommended. The water and air samples results will be used as a referenced for future monitoring. The EIA results show the level of risk of the environmental impacts identified. The high risk impacts were mainly air emissions (GHGs and hazardous $\mathrm{H}_{2} \mathrm{~S}$ ) and oil spillages. The extreme amount of gases exhausted from the heavy duty machinery and flaring were significant. Comprehensive monitoring programs are essential as are reduction of $\mathrm{SO}_{2}$ and $\mathrm{H}_{2} \mathrm{~S}$ emissions. The use of standardised environmental protection procedures are necessary to minimise spillages and the use of chemical spill contingency plans (SCPs). Surprisingly, levels of noise and light were rated as a moderate risk along with industrial inorganic and organic wastes and hazardous materials. Although these represent small quantities from maintenance departments, consideration is still important. The remaining impacts were rated as minor risk and low risk.

\subsection{Interviews findings}

Following the identification of environmental impacts from the EIA, the views of the upstream petroleum personal and stakeholders on how to minimise these impacts was considered. Fifty-six semi-structured interviews were conducted from a diverse sample. Table 8 shows a classification of the interviewees, with each interviewee categorised with a code based on his/her organisation and location. Interviews were recorded and assessed using a qualitative analysis approach (thematic analysis). This type of analysis allows the discussion to be investigative. Open, semi-open and closed questions were used to allow interviewees to elaborate on their answers and provide further insights into the subject under study.

The interviewees were selected from different organisations who are directly and indirectly involved in the upstream petroleum operations. Three upstream petroleum companies which represent the fieldwork area (El Sharara oil field, El Feel oil field, and Al Wafa oil field) were considered along with one midstream company (Azzawya Oil Company), which represents the importer and exporter of the produced oil from the western region. Five interviews were conducted at the NOC, which is the state owned administrator of the Libyan petroleum sector. Two interviews were conducted with personnel from the Environmental General Authority (EGA). The EGA is the government monitoring body and watchdog that has direct relations with the petroleum sector. The sample of interviewees were carefully selected to gain a diverse, general understanding of the environmental issues from a variety of sources and levels of the workforce and to achieve more realistic, reliable results. 
Table 8 Overview of the interviews

\begin{tabular}{|c|c|c|c|c|}
\hline Classification & Organisation & $\begin{array}{l}\text { Code of } \\
\text { interviewee }\end{array}$ & City & $\begin{array}{c}\text { No of } \\
\text { interviews }\end{array}$ \\
\hline $\begin{array}{l}\text { Petroleum sector Policy } \\
\text { Makers (PSPM) }\end{array}$ & $\operatorname{PSPM}(\mathrm{A})$ & $\mathrm{A} 1, \mathrm{~A} 2, \ldots, \mathrm{A} 5$ & Tripoli & 5 \\
\hline $\begin{array}{l}\text { Azzawya Oil Company } \\
\text { (AOC) }\end{array}$ & $\begin{array}{l}\text { Azzawya Oil } \\
\text { Company (B) }\end{array}$ & $\mathrm{B} 1, \mathrm{~B} 2, \ldots, \mathrm{B} 5$ & Azzawya & 5 \\
\hline $\begin{array}{l}\text { Environment General } \\
\text { Authority (EGA) }\end{array}$ & EGA $(C)$ & $\mathrm{C} 1$ and $\mathrm{C} 2$ & Tripoli & 2 \\
\hline $\begin{array}{l}\text { El Sharara Oil Field } \\
\text { (ESOF) }\end{array}$ & ESOF (D) & $\mathrm{D} 1, \mathrm{D} 2, \ldots, \mathrm{D} 15$ & Murzuq Desert & 15 \\
\hline $\begin{array}{l}\text { El Feel Oil Field } \\
\text { (EFOF) }\end{array}$ & EFOF (E) & $\mathrm{E} 1, \mathrm{E} 2, \ldots, \mathrm{E} 16$ & Murzuq Basin & 16 \\
\hline $\begin{array}{l}\text { Al Wafa oil field } \\
\text { (AWOF) }\end{array}$ & AWOF (F) & $\mathrm{F} 1, \mathrm{~F} 2, \ldots, \mathrm{F} 8$ & Ghadames Desert & 8 \\
\hline Senior Managers (SM) & $\mathrm{SM}(\mathrm{G})$ & $\mathrm{G} 1, \mathrm{G} 4, \ldots, \mathrm{G} 4$ & $\begin{array}{l}\text { From all the } \\
\text { above }\end{array}$ & 4 \\
\hline Total number of interviews & & & & 56 \\
\hline
\end{tabular}

Figure 4 Environmental issues at upstream oil and gas operations based on interviewee responses (see online version for colours)

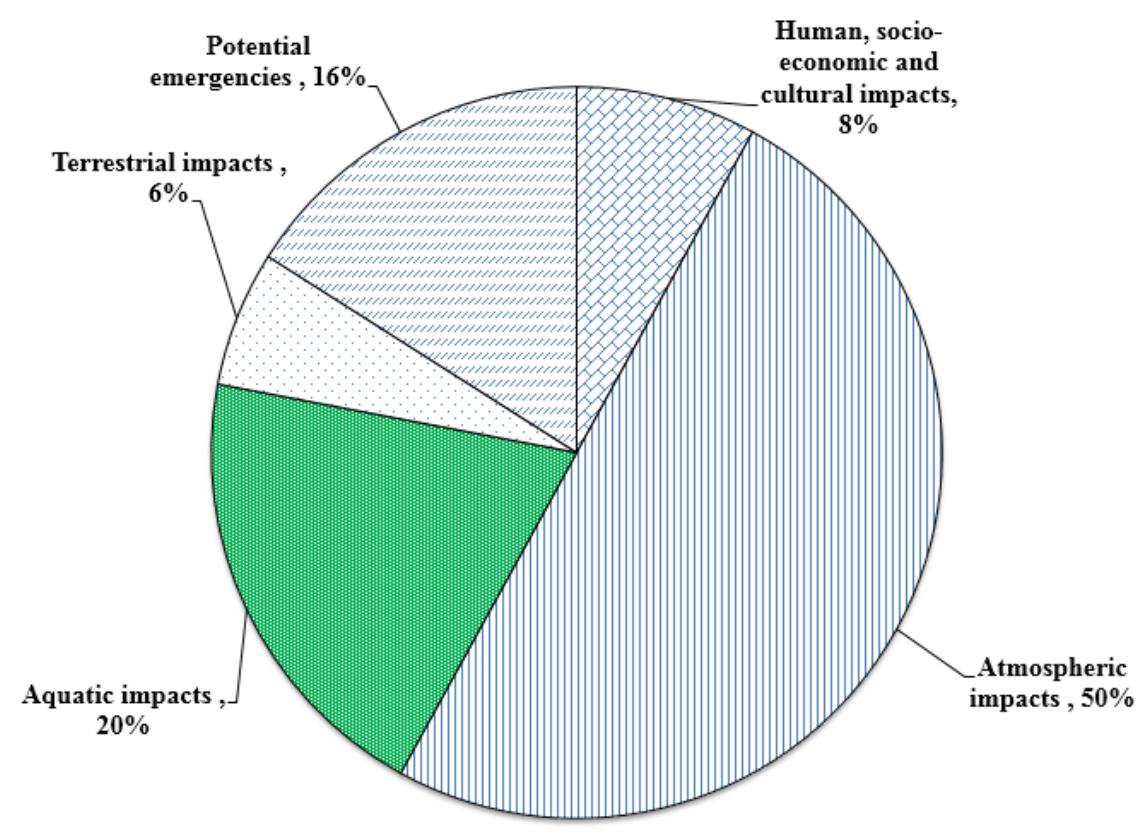

As shown, the results imply that around $50 \%$ of the total impacts are atmospheric with around $20 \%$ aquatic. These categories are further broken down in the following figure. Interviewees further classified each category of the impacts. For example, atmospheric 
impacts were split into two; emission from combustion of engines and turbines, and gas flaring and venting.

Figure 5 Classifications of identified environmental impacts (see online version for colours)

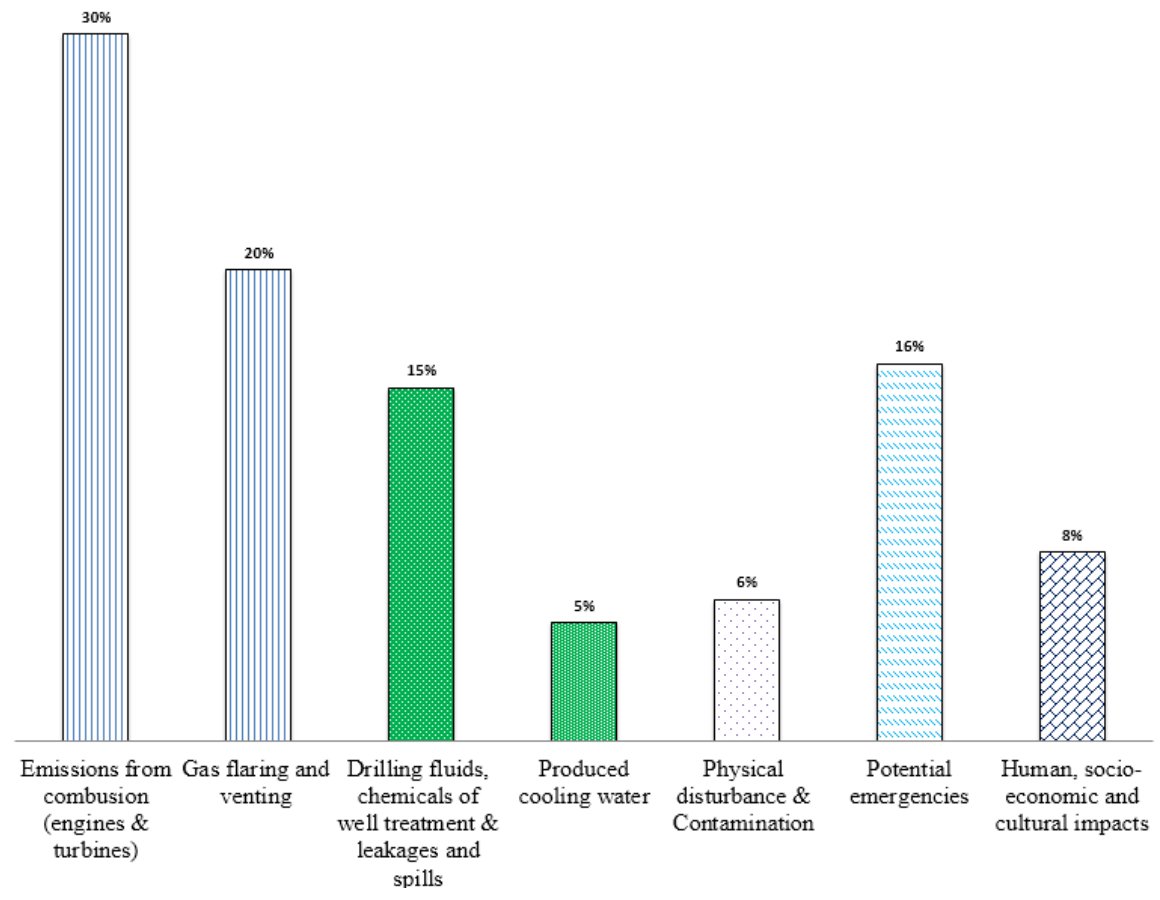

Interviewees were also asked to rate the environmental performance in their companies, yielding the breakdown in Table 9.

Table 9 Company environmental performance

\begin{tabular}{lccc}
\hline Interviewee company & Excellent & Moderate & Low \\
\hline Petroleum Sector Policy Makers (PSPM) & $30 \%$ & $60 \%$ & $10 \%$ \\
Azzawya Oil Company (AOC) & $0 \%$ & $10 \%$ & $90 \%$ \\
Environment General Authority (EGA) & NA & NA & NA \\
El Sharara Oil Field (ESOF) & $15 \%$ & $50 \%$ & $35 \%$ \\
El Feel Oil Field (EFOF) & $10 \%$ & $55 \%$ & $35 \%$ \\
Al Wafa oil field (AWOF) & $20 \%$ & $40 \%$ & $40 \%$ \\
Senior Managers (SM) & $90 \%$ & $10 \%$ & 0 \\
\hline
\end{tabular}

The results show there is a clear contradiction between the views of policy makers and senior managers compared to the rest of employees. This contradiction indicates either a lack of honesty from senior employees or a lack of awareness from lower level employees. However, a senior manager shed light stating that: 
.....Terrible leadership and management is the cause of bad environmental performance at the petroleum sector, and most of senior managers will try to defend themselves knowing it is mainly their fault....[ESOFD7]. ESOFD7 is the code of the interviewee which refers to the Interviewee Company and number (see Table 8).

Interviewees were prompted to comment on the extent of the effort their companies gave to environmental protection, with results summarised in Table 10.

Table 10 Companies environmental performance based on employee perception

\begin{tabular}{lccc}
\hline Answers & Yes & No & I do not know \\
\hline Petroleum Sector Policy Makers (PSPM) & $40 \%$ & $60 \%$ & 0 \\
Azzawya Oil Company (AOC) & $20 \%$ & $80 \%$ & 0 \\
Environment General Authority(EGA) & NA & NA & NA \\
El Sharara Oil Field (ESOF) & $30 \%$ & $70 \%$ & $15 \%$ \\
El Feel Oil Field (EFOF) & $26 \%$ & $74 \%$ & 0 \\
Al Wafa Oil field (AWOF) & $20 \%$ & $75 \%$ & $5 \%$ \\
Senior Managers (SM) & $45 \%$ & $55 \%$ & 0 \\
\hline
\end{tabular}

The majority of interviewees felt their company did not sufficiently support attempts to minimise environmental impacts. Those who responded positively referred specifically to the efforts directed towards health and safety (H\&S) and potential emergencies. It is agreed that efforts regarding potential emergencies are satisfactory, but that atmospheric and terrestrial impacts had never been considered by their companies. An interviewee from Azzawya Oil Company said:

......There are good practices regarding health and safety protection in my company, but there is no adequate consideration regarding the environment... [AOCB3].

Another senior manager from the EGA adds:

....There is a clear resistance and lack of motivation towards the implementation of voluntary environmental management systems, there is lack of compliance with essential basic requirements of environmental regulations rather than the volunteering EMSs...[EGAC1].

From Al Wafa oil field a maintenance engineer stated that:

...... One way to contribute to sustainable development and reduction of fossil fuels consumption by Libyan petroleum companies investment in renewable energy generation using solar and wind .....[WOFF2]

It was noted from another senior manager in the EGA that lack of supervision and environmental monitoring is one of the causes of the poor attitude of oil companies towards the environment. This demonstrates the key issue of leadership and management of Libyan upstream companies. A newly employed production engineer at El Sharara oil field stated that:

.....Leadership and management issues of my company and the oil and gas sector in general is mainly associated with lack of effective management. Corruption from previous regime still exists in the sector and it is one of the key causes of unsustainable petroleum production...[ESOFD11]. 
Table 11 Recommendations to minimise environmental impacts

\begin{tabular}{lc}
\hline Recommendation & No. of interviewees \\
\hline Academic research to support decision making & 50 \\
Implementation of EMSs and sustainable development tools & 47 \\
$\begin{array}{l}\text { Training and awareness on how environmental impacts could be } \\
\text { minimised }\end{array}$ & 42 \\
$\begin{array}{l}\text { Seek assistance from experienced international oil companies for } \\
\text { managing environmental impacts }\end{array}$ & 39 \\
Establishing the environmental policies and regulations & 34 \\
\hline
\end{tabular}

As a part of the interview process, a question was asked concerning how environmental impacts at the upstream operations might be reduced. The question aimed to gain the views of interviewees based on their experience in the field. Table 11 shows the key repeated recommendations provided by interviewees. General assumptions have been made from the interviews with regards to potential solutions to a more environmentallyfriendly and sustainable approach. The responses are taken from 56 interviewees and presented based on the frequency of comments.

It is concluded that academic and scientific research is essential for decision making in their companies and was recommended by 50 interviewees. The implementing of modern approaches and EMS was recommended by 47 interviewees. Environmental awareness and training was highly recommended along with seeking external specialist support and consultancy from experienced international companies. The establishment of strict environmental policies and regulation was also a major recommendation from the interviewees. These views are consistent with literature findings such as Irhoma et al. (2013), Goodland (2013) and Bindra et al. (2014).

A senior manager from the NOC stated:

.....I believe it is very important to conduct scientific research studies to support decision making and produce empirical results to help make the right decisions for the sector improvements, research and development I think are extremely important .....[SMG2].

Another interviewee stated:

....For oil fields, it is important to use new modern approaches of sustainability and environmental performance. I think it is our challenge to get such approaches implemented, and one way of making it easy is to use the experience of international experienced companies to assist in such projects....[AOCC 3$]$

The implementation of SD approaches and EMS are very important to help improve environmental performance (Campos, 2012) but there are essential requirements to provide the base for such tools to be easily implemented. These requirements were identified by Irhoma et al. (2013) in their study titled 'Analysis of the barriers to EMS implementation in the Libyan oil industry'. The study found that barriers are associated with leadership and management, resources (human, technical and financial resources) and political and external forces. It is important, therefore, that companies improve their management procedures before the implementation of EMS's.

Training and education were considered a key issue by most interviewees in the study, in addition to seeking advice from internationally experienced oil companies in 
technical matters. Establishing and regularly updating environmental policies and regulations was deemed a significant requirement. Most of the interviewees appreciated the importance of SD methodologies and EMS implementation, with 95\% referencing its importance.

A senior manager from the NOC stated that:

.....all developed countries view sustainability and environmental management as a priority in their sectors, It is the time that we need to do so, especially in an important sector like petroleum sector....[PSPMA2].

\subsubsection{Political changes}

The research work, including fieldwork visits, was conducted after the political changes in Libya. Libya witnessed eight months of civil war, which led to significant changes and a total shutdown to the petroleum sector. Most of the data collected were gained after the changes, which allowed honest responses from interviewees that may have previously put their jobs at risk. This increased democracy and freedom to express opinions enhances the validity of the study results. Organisation culture has transformed since the changes in the political system of the country.

An employee from Al Feel oil field stated:

.... If you were questioning me the same questions before the revolution (17th Feb, 2011), I will simply refuse to participate in this study, or I will just say that everything is going well and fine, because of fear of consequences, but now, I am not scared from anyone, and I can tell exactly how I feel and think about the work and company..... [EFOFE6].

\section{Discussion}

The continual reliance on the petroleum sector for the country's revenue and economic stability is one of the important challenges Libyan policy makers face. SD is an essential concept to be developed and promoted in the Libyan petroleum sector. Similar to any other country, Libya needs to boost its economy, maintain and increase its sources of income and establish financial stability post war. With increasing pressures from the international community, the United Nations and other non-government organisations (NGOs), the main sector in the country is required to address its environmental impacts within a strategic development plan. As stated by a policy maker from the NOC:

... Petroleum developmental strategies must focus on the environmental dimension and should have a roadmap on how to enhance the overall environmental performance of the sector... [PSPMA5].

The significance of SD is recognised by policy makers, however, no actions appear to be taken on the ground. This might be due to the lack of effective strategy and legal compliance.

The results in this paper identify the major environmental impacts at the upstream oil and gas operations in the western region of Libya specifically in Murzuq desert. EIA was carried out to assess the major influences based on their risk category. The risk category calculated relies on the severity of the impact and the probability-based rate of occurrence. Qualitative analysis using semi-structured interviewees compliment the 
findings of the EIA and assess the awareness and viewpoints of a carefully selected sample.

EIA results show the high risk of environmental impacts are those related to air emissions (combustion and flaring) and those that impact land and soil such as spillages of chemical wastes. Other organic and inorganic wastes were considered moderate risk, with noise and other terrestrial impacts minor rise. Underground water, noise and other Socio-economic and socio-cultural impacts were ranked as low, but not insignificant risk; studies should be conducted to evaluate reduction options. A major issue witnessed with all the upstream companies visited is the lack of environmental reporting and datastoring. This is clearly expected in an environment where there are no government monitoring procedures to force the companies to initiate environmental recording and reporting procedures. EIA recommends a SCP to be established with clean up materials and equipment being available on site along with ongoing environmental training to all associated with the project. In addition, studies into soil remediation technologies along with the use of oil sludge disposal and recovery technologies for treatment purposes as advised by $\mathrm{Hu}$ et al. (2013) should be adopted. To minimise emissions, flaring gas recovery systems (GRS) are required at all field flaring stations. Companies should invest in carbon storage technologies and conduct a set of energy saving feasibility studies. These studies will allow simple and effective energy savings throughout the processes. Industrial inorganic wastes and hazardous materials were ranked as high risk, therefore, a detailed waste management plan (WMP) must be developed and implemented. A comprehensive monitoring program is recommended to improve air emissions along with technologies to minimise $\mathrm{SO}_{2}, \mathrm{H}_{2} \mathrm{~S}$, and $\mathrm{NO}_{\mathrm{X}}$. Further, increasing the energy efficiency of diesel engines and heavy duty machines is essential, which could be assisted by replacement of old machines with more advanced and environmental-friendly options. Leaks, spillage and other wastes were ranked as a minor risk.

Interview findings complement EIA results and offer an understanding of the environmental issues from a human perspective. Findings were generated which show the diversity of viewpoints and understanding from various interviewees from the Libyan upstream companies. This analysis concludes that the major environmental impacts are atmospheric associated with gas flaring, exhausts from diesel engines, turbines and other heavy duty machines. Another major concern relates to aquatic sources, which include contaminated water, drilling fluids, chemicals, leaks and spills. A number of key recommendations were received from the interviews which include the necessity of academic and scientific research studies to improve the performance of the Libyan petroleum sector, in addition to the implementation of international management standards and sustainability improvement concepts. Lack of strict sustainability policies and laws has contributed to the low environmental performance. It is important for the Libyan petroleum sector to seek external consultancy from international experienced and expert organisations in the field of sustainability and in parallel, raise sustainability awareness within the petroleum companies.

The results of this paper represent a novel attempt to classify and quantify the environmental impacts at the upstream petroleum industry, yet it has two limitations. The first is that the EIA conducted was implemented at a basic level and to a limited project area. Intensive EIA studies should be conducted to gain more comprehensive and in depth identification of impacts. Second, the study was mainly targeting the upstream operations of oil and gas companies in the western region of Libya; it did not include 
similar in eastern regions. It is known, however, that Libyan petroleum companies run by the NOC share the same organisational and political structure and culture and therefore should share the same environmental issues.

\section{Conclusions}

The first of its kind, this study presents a novel contribution to identify the environmental impacts at Libyan petroleum companies' upstream operations. The major impacts are identified using a mixed methods approach including EIA, fieldwork trials and qualitative analyses of semi-structured interviews. Clear understanding of the environmental performance of the Libyan upstream companies was gained. The sector suffers from high environmental degradation and lack of effective environmental management. It was found from the EIA that Libyan petroleum upstream operations have various environmental impacts, which were categorised. The highest risk impacts are related to waste issues of soil, which include the large scale catastrophic events throughout the upstream phase, as well as industrial inorganic wastes and hazardous materials. However, these high risk, aquatic impacts represented only $20 \%$ of overall impacts. The majority of impacts were classified as atmospheric; $50 \%$ associated with gas flaring, venting and the exhausts of the heavy duty machines such as diesel engines and turbines. Atmospheric impacts were ranked with both high and minor risk. The high risk impacts were associated with dangerous gases from flaring and power generation such as $\mathrm{SO}_{2}, \mathrm{H}_{2} \mathrm{~S}$ and $\mathrm{NO}_{\mathrm{X}}$. Minor risk emissions were the rest of gases including $\mathrm{CO}_{2}$. Findings from this study revealed additional management and leadership issues, lack of sustainability awareness and lack of implemented standardised sustainability approaches in the sector.

It is recommended that:

- WMPs and SCPs be conducted to identify practical and realistic ways of minimising waste, spills and leaks.

- Scientific studies are essential to examine and evaluate environmental issues such as in depth EIAs and LCA.

- Flaring GRS should be installed at all flaring stations to minimise the amount of emissions.

- Environmental training and awareness programs within the upstream petroleum companies targeting employees at all levels.

- Implementing energy saving feasibility studies to all of the current power generation turbines and heavy duty machines to allow energy saving and efficiency increase.

- Oil sludge treatment such as sludge disposal technologies be conducted.

- Enhance leadership and effective supervision within the petroleum upstream companies by the integration of standardised sustainability approaches, such as ISO4001 and EMAS.

- Empower regulatory authorities and government organisations, such as the EGA to monitor environmental compliance.

- Establish strict policies and regulations toward sustainability. 


\section{References}

Abaza, H., Bisset, R. and Sadler, B. (2004) Environmental Impact Assessment and Strategic Environmental Assessment: Towards an Integrated Approach, UNEP/Earthprint, Geneva, Switzerland.

Abusa, F.M. and Gibson, P. (2013) 'TQM implementation in developing countries: a case study of the Libyan industrial sector', Benchmarking: An International Journal, Vol. 20, No. 5, pp.693-711.

Agnaia, A.A. (1997) 'Management training and development within its environment: the case of Libyan industrial companies', Journal of European Industrial Training, Vol. 21, No. 3, pp.117-123.

Al-Drugi, A. and Abdo, H. (2012) 'Investigating the development of environmental disclosures by oil and gas companies operating in Libya: a comparative study', International Journal of Economics and Finance Studies, Vol. 4, No. 2, pp.1-10.

Ali, I. and Harvie, C. (2013) 'Oil and economic development: Libya in the post-Gaddafi era', Economic Modelling, Vol. 32, pp.273-285.

Bayagbon, A.M. (2011) Impact Assessment of the Environmental Protection Policies in the Upstream Oil Industry in Nigeria, Master dissertation, North-West University, Potchefstroom Campus.

Bindra, S.P., Hamid, A., Salem, H., Hamuda, K. and Abulifa, S. (2014) 'Sustainable integrated water resources management for energy production and food security in Libya', Procedia Technology, Vol. 12, pp.747-752.

BPa (2014) BP Statistical Review of World Energy June 2014, British Petroleum [online] http://www.bp.com/content/dam/bp/pdf/Energy-economics/statistical-review-2014/BPstatistical-review-of-world-energy-2014-full-report.pdf (accessed 18 June 2014).

$\mathrm{BPb}$ (2002) Environmental and Social Impact Assessment Methodology, BTC Project ESIA, Georgia [online] http://www.bp.com/liveassets/bp_internet/bp_caspian/bp_caspian_en/ STAGING/local_assets/downloads_pdfs/xyz/BTC_English_ESIAs_Georgia_Content_BTC ESIA_Sectio-dology_En_pdf (accessed 28 April 2014).

Bruhn-Tysk, S. and Eklund, M. (2002) 'Environmental impact assessment - a tool for sustainable development?: A case study of bio fuelled energy plants in Sweden', Environmental Impact Assessment Review, Vol. 22, No. 2, pp.129-144.

Bukhari, A. (2013) 'Sustainable energy and environment: objectives, challenges, the needs and the roadmap', Conference presentation in Sustainable Environment, Climate Change and Renewable Energy for Oil and Gas Industry, 21st Joint GCC_Japan Environment Symposium, Doha, Qatar, 5-6 February.

Campos, L.M.S. (2012) 'Environmental management systems (EMS) for small companies: a study in Southern Brazil', Journal of Cleaner Production, Vol. 32, pp.141-148.

Darling, T. (2005) Well Logging and Formation Evaluation, Elsevier Science, Amsterdam.

Eidinov (2004) Regulatory Basis of Environmental Impact Assessment: Methodological Aspects of Environmental and Socio-economic Impact Assessment, AGIP KCO, Kazakh Agency of Applied Ecology [online] http://www.unece.org/fileadmin/DAM/env/eia/documents/ CentralAsiaGuidelines/Annex\%204\%20-\%20English.pdf (accessed 7 January 2013).

Energy Information Administration (EIA) (2014) Monthly Energy Review, US Department of Energy [online] http://www.eia.gov/totalenergy/data/monthly/pdf/mer.pdf (accessed 23 September 2014).

European Commission (2010) Registration of Crude Oil Imports and Deliveries in the European Union (EU27), No. 1, (INTRA + EXTRA EU), European Market Observatory for Energy [online] http://ec.europa.eu/energy/observatory/oil/import_export_en.htm (accessed 15 June 2014). 
Garg, A., Vishwanathan, S. and Avashia, V. (2013) 'Life cycle greenhouse gas emission assessment of major petroleum oil products for transport and household sectors in India', Energy Policy, Vol. 58, pp.38-48.

Gilbuena Jr., R., Kawamura, A., Medina, R., Nakagawa, N. and Amaguchi, H. (2013) 'Environmental impact assessment using a utility-based recursive evidential reasoning approach for structural flood mitigation measures in Metro Manila, Philippines', Journal of Environmental Management, Vol. 131, pp.92-102.

Goodland, R. and Daly, H. (1996) 'Environmental sustainability: universal and non-negotiable', Ecological Applications, Vol. 6, No. 4, pp.1002-1017.

Goodland, R.J.A. (2013) Libya: The Transition to Environmental Sustainability, Library of Congress Cataloguing-in-Publication Data, ISBN: 978-0-9792179-0-6.

Green Oil and Akakus (2008) Environmental Baseline Survey, Azzawya Oil Refinery Co. Final Report: V0.2.

Hu, G., Li, J. and Zeng, G. (2013) 'Recent development in the treatment of oily sludge from petroleum industry: a review', Journal of Hazardous Materials, Vol. 261, pp.470-490.

Ikein, A. (1990) The Impact of Oil on a Developing Country, Praeger, New York.

Irhoma, A., Su, D.Z. and Higginson, M. (2013) 'Analysis of the barriers to environmental management systems implementation in the Libyan oil industry', Key Engineering Materials, Vol. 572, pp.672-677.

Kharaka, Y.K. and Otton, J.K. (2003) Environmental Impacts of Petroleum Production: Initial Results from the Osage-skiatook Petroleum Environmental Research Sites, Osage County, Oklahoma, US Department of the Interior, US Geological Survey.

Melitah Oil and Gas B.V. (2014) Al Wafa Oil Field [online] http://www.mellitahog.ly/sites/details.php?id=10 (accessed 4 June 2014).

Modak, P. and Biswas, A.K. (Eds.) (1999) Conducting Environmental Impact Assessment in Developing Countries, United Nations University Press, Tokyo.

Mohamed, A.M.A., Al-Habaibeh, A. and Abdo, H. (2013) 'An investigation into the current utilisation and prospective of renewable energy resources and technologies in Libya', Renewable Energy, Vol. 50, pp.732-740.

National Oil Corporation (NOC) (2014) Libyan National Oil Corporation [online] http://noc.ly/index.php/en/ (accessed 1 June 2014).

Nooman, D.C. and Curtis, J.T. (2003) 'Exploration and production waste management', Journal of Petroleum Technology, Vol. 85, No. 3. pp.32-41.

Organisation of the Petroleum Exporting Countries (OPEC) (2014) Libya Facts and Figures, Organisation of the Petroleum Exporting Countries [online] http://www.opec.org/opec_web/en/about_us/166.htm (accessed 7 June 2014).

Rosenfeld, P.E. and Feng, L.G.H. (2011) Risks of Hazardous Wastes, William Andrew Publishing, Boston.

Saleh, P.E. and Ibrahim, M. (2006) 'Prospects of renewable energy in Libya', Solar Physics and Solar Eclipses (SPSE 2006), Vol. 1.

Schweitzer, D. (2010) Oil Companies and Sustainability: More than Just an Image? [online] http://deepblue.lib.umich.edu/bitstream/handle/2027.42/77607/dschwei.pdf (accessed 14 September 2014).

Toro, J., Requena, I., Duarte, O. and Zamorano, M. (2013) 'A qualitative method proposal to improve environmental impact assessment', Environmental Impact Assessment Review, Vol. 43, pp.9-20.

United Nations Environmental Program (UNEP) (1997) 'Oil industry international exploration, \& production forum', Environmental Management in Oil and Gas Exploration and Production: An Overview of Issues and Management Approaches, Vol. 2, UNEP/Earthprint.

Vandewalle, D.J. (1998) Libya since Independence: Oil and State-building, Cornell University Press, USA. 
Wood, C. (2003) Environmental Impact Assessment: A Comparative Review, Pearson Education, Essex.

World Commission on Environment and Development (WCED) (1987) Our Common Future, Oxford University Press, Oxford.

Zaky, O. (2013) Reputation Drivers for Oil and Gas Sector. How Do Oil and Gas Companies Leverage on their Sustainability Reports to enhance their Corporate Reputation? A Qualitative Content Analysis for Companies Operating in Oil and Gas, Masters, Politecnico di Milano University. 